\title{
A festa de Ave Cesaria: migração, nostalgia e memória nas mídias digitais
}

\author{
Otávio Cezarini ÁVILA ${ }^{1}$
}

\begin{abstract}
Resumo:
Este artigo trata da nostalgia alinhada a duas questões fundamentais da comunicação. A primeira é a transformação da temporalidade pela midiatização. O uso de plataformas digitais, como o Youtube, permitiu que a velocidade de acesso acompanhe as ágeis e fugazes demandas humanas. A segunda questão parece caminhar em paralelo à comunicação, mas no entendimento empreendido, migração e comunicação são parte do mesmo processo social de troca, o qual modifica-se com o tempo e o espaço. Para falar de migração, nostalgia e tempo nas mídias digitais, o artigo evoca um videoclipe publicado em 2014, no Youtube. Além das questões tratadas anteriormente, o produto é analisado a partir da sua natureza artística e mercadológica, fomentadas pelas interações dos usuários, aqui chamadas de divãs digitais da própria memória e nostalgias de um tempo que foi, mas ainda está.
\end{abstract}

Palavras-chave: migração; memória; nostalgia; mídias digitais; videoclipe.

\section{The Ave Cesaria party: migration, nostalgia and memory in digital media}

\begin{abstract}
:
This article addresses nostalgia aligned with two fundamental communication issues. The first is the transformation of temporality through mediatization. The use of digital platforms, such as Youtube, has allowed the speed of access to keep up with the fast and fleeting human demands. The second question seems to go hand in hand with communication, but in the understanding undertaken, migration and communication are part of the same social process of exchange, which changes over time and space. To talk about migration, nostalgia and time in digital media, the article evokes a music video published in 2014 on Youtube. In addition to the issues discussed above, the product is analyzed from its artistic and marketing nature fostered by user interactions, which here called digital divans of memory itself and nostalgia for a time that was, but still is.
\end{abstract}

Keywords: migration; memory; nostalgia; digital media; video clip.

\section{La fiesta de Ave Cesaria: migración, nostalgia y memoria en los medios digitales}

\section{Resumen:}

Este artículo aborda la nostalgia en línea con dos cuestiones fundamentales de la comunicación. El primero es la transformación de la temporalidad a través de la mediatización. El uso de plataformas digitales, como Youtube, permitió que la velocidad de acceso se mantuviera al día con las ágiles y fugaces demandas humanas. La segunda pregunta parece ir de la mano de la comunicación, pero en el entendimiento asumido, la migración y la comunicación forman parte de un mismo proceso de intercambio social, que cambia con el tiempo y el espacio. Para hablar de migración, nostalgia y tiempo en los medios digitales, el artículo evoca un videoclip publicado en

\footnotetext{
${ }^{1}$ Doutorando em Comunicação e Cultura pela Universidade Federal do Rio de Janeiro.

E-mail: otavioczav@gmail.com.
} 
2014, en Youtube. Además de las cuestiones comentadas anteriormente, se analiza el producto en función de su carácter artístico y de marketing propiciado por las interacciones de los usuarios, aquí llamadas de divanes digitales de la propia memoria y nostalgias de un tiempo que fue, pero sigue siendo.

Palabras clave: migración; memoria; nostalgia; medios digitales; videoclip.

\section{Introdução}

Huyssen (2000) credita às mídias o potencial de criar memórias imaginadas que passam a ser o foco do ordenamento subjetivo no contemporâneo. Argumenta ele (2000, p. 11) que, se a cultura modernista foi energizada por aquilo que convém chamar de "futuro de presente", nesta cultura erigida a partir da década de 1980 é o "passado do presente" que se estabelece como experiência e sensibilidade sobre o tempo. O presente volta-se ao passado no contemporâneo. Com o fim das grandes narrativas e seus finais utópicos, somando ao desenvolvimento de tecnologias que acarretam na aceleração espaço-temporal, a sociedade se vê diante de um medo do esquecimento e responde a isso rememorando, remasterizando, arquivando compulsivamente cada aspecto da vida, inclusive aqueles considerados banais e, por isso, dispensáveis, na antiga e limitada capacidade de registro disponibilizada pelas fitas cassetes, filmes de rolo e arquivos de aço.

Neste introdutório, convém pontuar a linha teórica das migrações, fenômeno constitutivo do homem, marcado contemporaneamente pela mesma aceleração tecnológica que lida com a memória. No fato migratório, as tecnologias redimensionam as distâncias territoriais e subjetivas porque reforçam o pertencimento ao lugar de origem e dificultam uma assimilação completa da sociedade de destino, entre outras modificações assinaladas por ElHajji (2011), ao enfatizar ele que as migrações atuais não podem se dissociar do simulacro midiático e do consumo. Mas migração é sempre um ato de emigrar e imigrar. Quem ruma a um destino sempre deixa outro. A não ser pelas populações nômades, as quais fazem da mobilidade seu sentido comunitário, a migração continuamente parte de uma escolha individual de deixar seu lugar de origem.

Sayad (1998) não apenas descreve a mobilidade geográfica, mas o efeito que ela tem nas subjetividades. O conceito de ghorba, central na obra do sociólogo argelino, explica ElHajji (2018, não paginado), significa um certo "estado mental de exílio" decorrente da permanente estranheza e provisoriedade vivida pelo migrante. Segundo Sayad (1998), mesmo na migração 
definitiva, o migrante continua a viver na provisoriedade, ao experimentar uma "dupla ausência" que aparece como mal-estar específico do migrante, convertendo o espaço social em espaço nostálgico. Assim, a questão não passa a ser mais a possibilidade de retorno a um lugar específico, mas da impossibilidade da volta a um lugar e tempo específicos.

A ghorba ainda é produzida pela ausência física, que, sabe-se a partir de Sayad (1998), não pode ser substituída por completo na aproximação com um real virtualizado. Não basta o contato por plataformas digitais de relacionamento com aqueles que permaneceram, sendo que é a perda do cotidiano em toda sua completude que se esvai. Ainda que haja o retorno, o tempo é o elemento irreconciliável.

O simulacro (BAUDRILLARD, 1991), que se reproduz na midiatização social e produz espetacularizações da memória em sua aproximação com o mercado de consumo, é chamado por Ribeiro (2018) de mercado da nostalgia. A autora afirma que, ligadas ao desejo pelo passado, a memória se torna parte de um capital narrativo midiático, unindo de vez a cultura da memória à cultura da mídia, como estratégia de ancoragens subjetivas que aproximam e fidelizam o consumidor pelo afeto e emoções.

Esta caracterização do simulacro da memória leva à análise de um videoclipe colocado à disposição nas mídias digitais em 2014. Disponibilizado no canal do Youtube do artista belga Stromae $^{2}$, a música Ave Cesaria põe o cantor no fundo (literalmente) do videoclipe e dá destaque a uma festa familiar típica cabo-verdiana, homenagem a sua principal referência musical: Cesaria Evora. Mas onde entra a memória a partir das construções teóricas introduzidas aqui? Por duas formas: 1) o videoclipe é todo produzido, ou seja, embora ele se confunda com uma filmagem amadora e antiga de uma festa familiar, o produto não passa de um simulacro e; 2) a figura da homenageada, Cesaria Evora, demarca o sentimento migrante relacionado à nostalgia do lugar originário pelo exílio, a saída.

$\mathrm{O}$ artigo tem como objetivo estabelecer uma aproximação entre a produção mercadológica (ainda que de um mercado cultural, como é o caso da música) do passado com o sentimento nostálgico daquilo que não pode se viver mais pela distância temporal e física. Soma-se a isso o meio pelo qual tal produto é veiculado. O Youtube, como mídia digital social,

\footnotetext{
${ }^{2}$ Link para o videoclipe analisado: https://www.youtube.com/watch?v=rO1VDCZh_Ko
} 
permite que o consumidor interaja com o produto e possibilita ao pesquisador avaliar sua receptividade. Quais particularidades de discursos emergem desse material, quais entendimentos e ancoragens compõem o universo discursivo do produto? Complementando a construção teórica e que encaminha a uma análise interpretativa-discursiva do videoclipe, foram selecionados os 20 comentários com maior relevância (curtidas, comentários e ranqueamento na caixa de interações) até 2019 para uma análise das percepções sobre a produção por esses usuários da plataforma.

\section{"Saudades do que a gente ainda não viveu". Neymar ou Sayad?}

Como este artigo trata do universo contemporâneo das mídias sociais digitais, cabe remeter ao que acontece nessa nova ágora de uso comum, de rápida popularização e memeficação. No início de junho de 2019, Neymar, a personalidade brasileira mais seguida nessa ambiência, foi surpreendido com uma denúncia de estupro. $\mathrm{O}$ caso não precisa ser relatado em detalhes porque foi amplamente veiculado e discutido nas mídias, mas, dentre tantos destaques, o conteúdo das conversas divulgadas pelo jogador com a modelo ganhou não só espaço nos inquéritos policiais como também na amplificação de sentidos do diálogo exposto. Rapidamente, as frases do jogador, como esta que dá título ao tópico, foram transformadas em novos conteúdos a partir daquilo que Braga (2006, p. 27) chama de um "sistema de circulação difuso".

Embora a difusão da frase resultasse em memeficações - essa nova linguagem que atravessa o campo da midiatização -, a saudade do que ainda não se viveu faz parte do universo das migrações em sua aproximação à nostalgia. A partir de uma entrevista produzida em 1975, Sayad (1998) registra a necessidade de migrar que homens de aldeias da Cabília, norte argelino, mantêm em relação à França. Sayad (1998, p. 32) argumenta que a antiga metrópole dominava as conversas como um "país da felicidade", mas ninguém sabia explicá-la de fato; uma França entendida como casa, que alimentava uma relação colonial subjetiva, inclusive aos que nunca pisaram em solo europeu. Mesmo que o texto trate da ghorba - que inclui a volta daqueles "franceses" que se tornam vacantes na aldeia, guardando consigo apenas o capital simbólico -, a reflexão de Sayad nos aproxima ao que também Handerson (2015), em sua tese sobre os haitianos, chamou de destino em ser dyaspora a predestinação migratória dos haitianos como 
fator constituinte identitário. Mesmo sem ter vivido, o sonho se mistura à nostalgia, como se, embora não vivido, fizesse parte de seu ser, de sua identidade e, por isso, necessário de ser realizado.

A junção desses casos apresenta um acréscimo. Transformada em meme, a "cantada" de Neymar se aproxima da natureza mnemônica, justamente porque o meme advém da memória. Em O gene egoísta (1976), Dawkins criou o termo referindo-se a ele como a unidade mínima na memória - "rascunhos" que podem ser repassados de maneira autônoma no ciberespaço - assim como o gene é a unidade mínima na genética. Mas o que é a memória e, mais profundamente, no que consiste a nostalgia nesse campo de estudo?

Primeiramente, a memória está ligada às experiências adquiridas pelo sujeito. Neste conceito estreito, ela se difere de uma saudade ou nostalgia dos homens da Cabília pelo não vivido. Mas Halbwachs (1990) advoga que a memória é coletiva, mesmo sendo individual o ato de lembrar. Seguindo a mesma dinâmica da constituição relacional do sujeito, a lembrança só se concretiza na medida em que nos colocamos na perspectiva de um grupo e nos identificamos com ele, como uma comunidade afetiva. É por isso que a utopia dos homens da Cabília em migrar atua dentro do esquema mnemônico, pois, embora projetada, é uma projeção reconstruída no presente a partir do passado do grupo. Resgatar a memória, torna-se, então, um trabalho criativo, pois pelo tempo presente ela é reconstruída.

A contribuição de Halbwachs (1990) se encontra na relação entre quadros longínquos, como a memória de uma "nação", caso da Cabília, e quadros próximos, ligados às memórias familiares, em que o objeto de análise do artigo parece encontrar mais força. Entretanto, a ancoragem a uma memória nacional está presente no videoclipe na medida em que o encontro familiar é remetido a um lugar e culturas nacionais diferentes das quais Stromae viveria atualmente.

Mas como a nostalgia se relaciona à memória? Antes, ainda, a nostalgia é um artifício da memória relacionada ao deslocamento humano. Segundo Ribeiro (2018), o vocábulo vem do século XVII, relativo a um desejo de voltar para casa como uma anomalia do afastamento da terra natal. Ribeiro (2018) também ressalta que a modernidade acrescenta o estatuto da nostalgia ao desejo de retorno de um tempo esvaído. Com as rupturas e acelerações, a nostalgia se apresenta como "uma relação problemática que indivíduos, grupos e sociedades estabelecem 
entre o tempo linear e direcionado ao progresso" (RIBEIRO, 2018, p. 2). Ela se converte em uma valorização do passado em detrimento do futuro, embora não o negue.

Essa valorização é erigida com a presença de uma cultura da mídia e suas narrativas sobre o passado. Ribeiro (2018, p. 3) ressalta que a produção de um "mercado da nostalgia" na modernidade, reflexo do desejo e do acúmulo excessivo de memória em uma temporalidade acelerada e fugaz, aciona diferentes sensibilidades em relação ao passado que podem adquirir sentidos variados que englobam "a melancolia e o saudosismo, mas também a positividade e a alegria".

Esse sentimento de nostalgia introduzido no contemporâneo e seu olhar para o passado se tornam uma indústria fortalecida também para as mídias que se utilizam do passado como simulacro. Segundo Huyssen (2000), espetacularizações que, se não podem ser categoricamente afirmadas como encobridoras da verdade - pois ela pertence ao passado e este é construído pelo presente - chamam-nos a atenção para o convívio entre o espetáculo da lembrança com a fábrica de esquecimentos conduzidas pela aceleração espaço-temporal.

\section{O maestro invertido e a diva dos pés descalços}

"Stromae" é a inversão silábica da palavra "maestro". Por trás do nome em verlan está Paul Van Hader, proveniente de uma família intercultural. A inversão do nome artístico não é apenas significado de um embaralhamento musical que o artista propõe: "uma espécie de mistura entre dance, rumba - vocês conhecem bem a rumba no Brasil, não? -, um pouco de salsa, coladeira [gênero de Cabo Verde], hip-hop e 'chanson française', é tudo isso" (PASSOS, 2014, não paginado). Stromae parece ganhar significado a partir da reflexão de Turner (2016), que explica o engajamento de jovens, especialmente de filhos de imigrantes, com a gíria verlan e o hip-hop na França, ao utilizarem-nos como forma de desestabilizar o monolinguismo e a singularidade étnica que configuram a categoria de cidadania nacional.

Se o destino dos imigrantes se depara com a multiplicação de identidades, Sayad (1998) lembra que para toda imigração há uma emigração. E é nesse registro que se encontra a obra musical de Cesaria Evora, um dos principais nomes da música cabo-verdiana. Em seus mais de 45 anos de carreira, ela cantou seu país como forma de lembrá-lo àqueles emigrados. Cabe ressaltar que a música é um fator importante. Pesquisa realizada pelo Observatório da 
Imigração de Portugal concluiu ser a manifestação cultural de mais forte definição da comunidade nacional (GRASSI, 2008).

O pequeno país da costa africana conta com uma população de aproximadamente 560 mil habitantes. Seguindo o padrão de países que conquistaram tardiamente a independência apenas em 1975, mais de 500 anos depois de sua “descoberta” por portugueses -, o país insular é caracterizado por uma diáspora estimada de 500 mil a 1 milhão de cabo-verdianos (HIRSCH, 2008; HENRIQUES, 2015).

Apesar de nascer e morrer em Mindelo, Cesaria Evora também fez da Europa fonte de sustento, como o povo de Cabo Verde. Foi sua ida para Lisboa e, depois, a Paris, que ajudou a morna e a coladeira a serem difundidas como ritmo por sua principal voz, aquela que seria imortalizada como a diva dos pés descalços (ARAÚJO, 2011). O jornalista cabo-verdiano Jorge Araújo escreveu sobre ela:

Aquela voz, a sua. Diz quem já a ouviu que continua a mesma. Suave, celestial. De novo, com doçura e sinceridade: "Posso não ser muito alegre, mas triste também não sou". Cize é muito mais que sentimentos. Muito mais que música. É Cabo Verde no mundo (ARAÚJO, 2011).

Cantando uma eterna nostalgia de uma Cabo Verde imaginada, a citação sobre a cantora relata a mescla entre alegria e tristeza da distância espaço-temporal. Petit Pays e Sodade, suas principais músicas, são videoclipes sentimentais, carregados de uma musicalidade, expressões verbais e imagens características do país. E foi essa personagem que atraiu Stromae a homenageá-la em Ave Cesaria.

Lançado em 2014 e somando mais de 21 milhões de visualizações pelo Youtube em 2019, o videoclipe levantou curiosidade sobre sua ficcionalidade, logo confirmada pela própria equipe de produção. Gravado em uma câmera VHS convencional, os seis minutos de filmagem apresentam um grande plano sequência de uma festa familiar, cuja câmera vai passando de mão em mão. O nível de realismo recebe contributo da gravação musical feita ao vivo, com o cantor ao fundo no palco da festa. As roupas, o perfil do público e a batida da música - com o inconfundível som do cavaquinho logo no início, sinal da ode à cultura lusófona - caracterizam a produção. A alegria é parte do videoclipe, como era de se supor ao ser reproduzida uma festa familiar. Sorrisos, bebidas, uma queda e o cochilo do figurante idoso aumentam o realismo da produção e demonstram aquilo que Ribeiro (2018) identificou como o lado feliz da nostalgia. 


\section{Uma tecnologia produtora de sensações e visualizações}

O interesse pelo Youtube se deve à modificação do hábito de consumo de vídeos e músicas a partir do streaming, vinculada ao desenvolvimento dos provedores de internet. O que o streaming potencializa, a fundo, é a transição cada vez mais veloz de conteúdos em detrimento do investimento de tempo humano e espaço de HD para que um filme ou um videoclipe sejam consumidos. Se a lógica dessa tecnologia potencializa o aumento de visualizações, como as sensações do humano reagem a esta nova forma de consumo?

A memória é uma das substâncias humanas interferidas pela ascensão tecnológica. Da oralidade passou à textualidade e, mais recentemente, à digitalização, privilegiando uma memória objetivada disponível em dispositivos automatizados e mais distantes dos corpos humanos, avaliam Puhl e Araújo (2012). Os autores relacionam a ambiência digital com as sensações atreladas às memórias individuais de modo que as interações construídas no Youtube, pelos usuários, potencializam a memória coletiva, ao mesmo tempo em que esta memória passa a servir como teia que dá sentido aos dados dessa rede.

Rosnay (2006) elucida a forma como a rede se constrói a partir da memória, explorando-a como a) explícita e b) implícita, no ambiente digital. A primeira é encontrada em bases de dados por mecanismos de busca e a segunda é autoconstruída, ou seja, "através de processo ecossistêmico, estabelece relação entre os conteúdos da memória explícita" (PUHL; ARAÚJO, 2012, p. 711), dados articulados por sistemas de categorização de vídeos e tomados por interações entre os usuários dessa rede.

Mas é a tecnologia que produz as sensações, como se afirma no título do tópico? Latour (2005) explica, a partir da Teoria Ator-Rede (TAR), que há atores humanos e não humanos nas associações que fazem o social. Primeiro, Latour (2005) entende que o social existe como um ente instável a partir da relação entre actantes; segundo, atores não-humanos podem ser mídias sociais, como ratifica Primo (2012, p. 633), ao afirmar que essas mídias "não são meros intermediários que simplesmente registram e transmitem informações", mas uma mediação que diferencia a associação produzida. Dessa forma, não são as tecnologias por si só que produzem sensações e, sim, a relação associativa com outros atores, no meu caso, humanos, que 
determinadas sensações podem ser geradas. Primo, e também Martino (2019), relatam a diferença de uma conversação a partir de diferentes mídias sociais.

Diferente do Facebook e do Instagram, que atuam com bases em perfis/páginas, o Youtube apresenta canais que têm como característica serem mais públicos. Com menos necessidade de informações pessoais, a plataforma se tornou negócio, não só de atores empresariais, como o caso de Stromae, cujo canal é vinculado ao seu trabalho artístico, mas de qualquer empreendedor digital.

A permanência dos mais variados públicos na plataforma sinaliza a capacidade segmentária no Youtube, cujo componente técnico permitiu que vídeos assistidos por mais tempo ganhem destaque, assim como as escolhas do próprio usuário - de busca, visualização e inscrição - determina o que aparecerá a ele mesmo como sugestões de vídeos.

A diversidade de temas, formatos e linguagens evidencia a ecologia midiática (SODRÉ, 2014) formada em torno da ação no Youtube. Os canais não servem apenas como transmissores de informações, mas modificam a própria realidade de consumo dos usuários ao permitirem que estes curtam/descurtam o produto e possam interagir entre si, mesmo antes de consumi-lo. No caso dos videoclipes, o streaming permite que sejam ouvidos e assistidos repetidas vezes e que haja acesso às letras das músicas por meio de outras abas (sites) ou mesmo nas postagens da letra por usuários, já comum na seção de comentários desse tipo de vídeo.

\section{Videoclipe: economia, semiótica e técnica}

A presença de videoclipes no Youtube passou a ser comum entre artistas e grandes produtoras. Para Soares (2007b, p. 1), o videoclipe se integra àquilo que Andrew Goodwin chama de "semblante midiático", ou seja, "a 'aparência' de um artista ou entidade que se formata a partir de um conjunto de produtos da indústria do entretenimento que orbitam sobre este artista, apontando para lógicas específicas e obedecendo a um projeto expressivo concreto". No caso de Stromae, a produção de um videoclipe que reproduza uma festa familiar cabo-verdiana traz à tona sua origem africana, mas não a ruandesa, de seu pai, e sim da referência (Cesaria Evora) que atuou no campo artístico de sua vida.

A necessária análise do videoclipe Ave Cesaria passa por outra complementaridade teórica analítica para as interações decorrentes de sua publicação no Youtube. Soares (2007a) 
transfere para o videoclipe três regras que Janotti Jr. (2004) elencou como endereçamento dos gêneros musicais na música popular massiva: regras econômicas, regras semióticas e regras técnicas.

As regras econômicas identificam os itinerários do consumo (JANOTTI JR, 2004). Para além da publicação pelo Youtube, a canção faz parte do álbum Racine Carrée, segundo álbum do cantor, cuja gravadora (Mosaert) também é sua. É interessante notar que uma das atuações da Mosaert está ligada ao mercado de vestuário, que pode ser notado no estilo inverso ao dress code das aparições do cantor. Seu nome invertido, em verlan, corresponde também ao seu estilo, que mistura androginia e muitas cores, presente na direção artística de Ave Cesaria, embora a baixa qualidade da imagem em VHS alinhada à pós-produção diminuam a incidência de cor no produto final. No entanto, o estilo das roupas e o cenário reforçam a identidade da marca - inclusive, a produção do videoclipe é destacada no site da gravadora.

Imagem 1 - Fotografia do videoclipe Ave Cesaria destacado no site da Mosaert

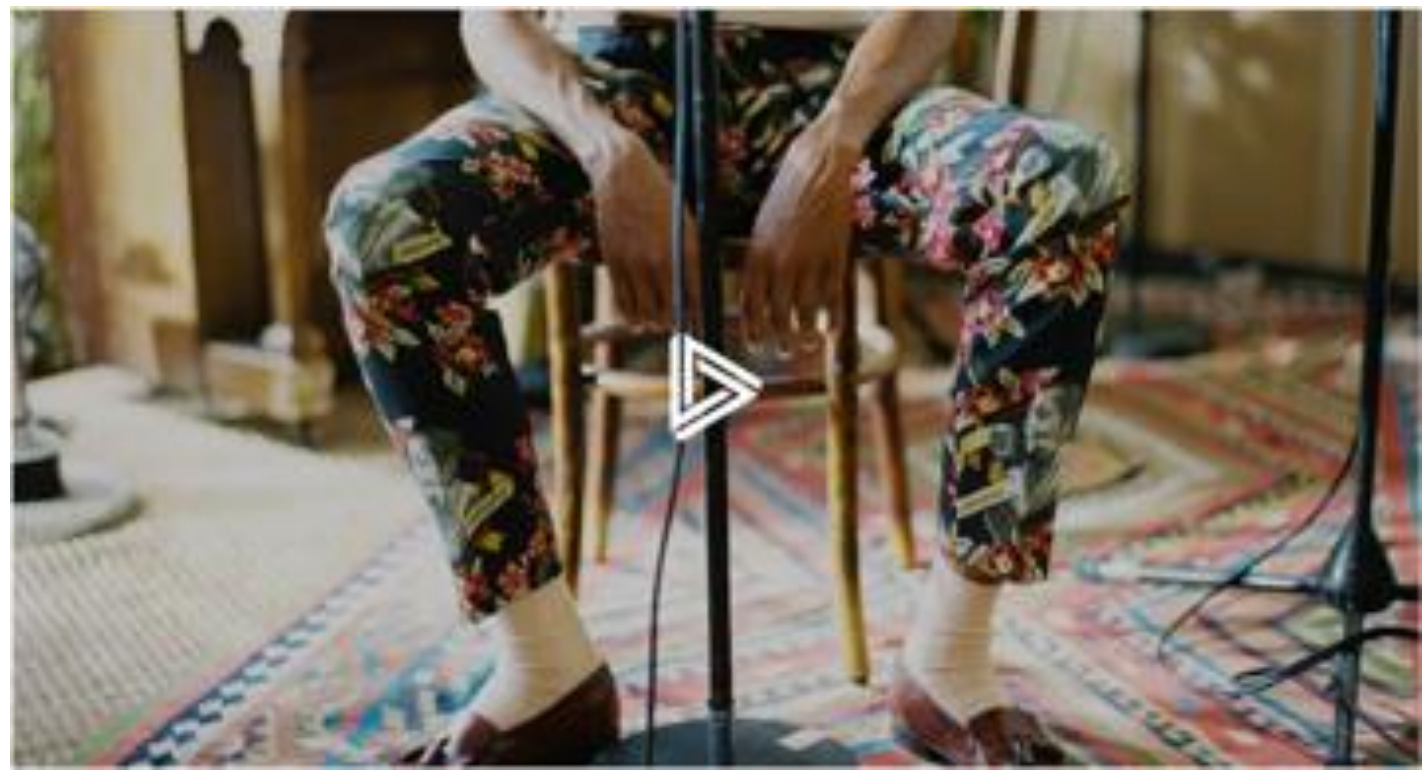

Um dos projetos da Mosaert são vídeos produzidos. Na imagem, destaque para as calças de Stromae, com o rosto e o nome de Cesaria Evora. No videoclipe, o design da roupa é imperceptível.

Fonte: site Mosaert.

As regras semióticas dizem respeito às estratégias de produção de sentido do texto musical e buscam diferenciar o autêntico e o cooptado das expressões comunicacionais exploradas. Dentro dessa regra há uma valoração das referências da produção, já evidenciadas 
no caso de Ave Cesaria. É justamente na fronteira entre o autêntico e o cooptado que o videoclipe se diferencia, em seu sentido da nostalgia feliz, da pátria mãe e familiar. Mesmo que a produção tivesse seguido referências artísticas, a grande referência é a própria memória familiar, inclusive na escolha do casting. Um dos produtores explica:

Making it feel real meant casting from real families and friends of friends we found in street casting. Basically our premise for the shoot was to enjoy it as much as if for real and our fantastic cast were really the ones who brought the vibe (SCHOLFIELD apud KNIGHT, 2014, não paginado). ${ }^{3}$

Scholfield (apud KNIGHT, 2014) também afirma que Stromae queria aparecer pouco, indicativo de que a construção do filme em um grande plano sequência explicaria o protagonismo das relações sociais, ao invés da imagem individual do cantor.

É sobre a essência relacional construída na canção que se localiza a regra técnica. Ela inclui a não presença do cantor no videoclipe, em detrimento ao ritmo da música e à configuração entre voz e instrumento; e da letra, evidenciada pela legenda, em inglês, em formato VHS. Este formato, somado à apresentação ao vivo da canção, mas evidentemente aprimorada na pós-produção sonora, buscam aproximar ainda mais o público àquele evento familiar. A técnica visual pouco rebuscada é justamente o fator vinculante entre a regra semiótica e a regra econômica, pois ao gerar a dúvida entre realidade e ficção, a produção se insere em um mercado de nostalgia, faceta do consumo contemporâneo.

\footnotetext{
3 "Fazer com que parecesse real significava inserir famílias reais e amigos de amigos que encontramos na rua. Basicamente, nossa premissa para a filmagem era curtir tanto quanto se fosse de verdade e nosso fantástico elenco foi realmente quem trouxe essa vibe" ((SCHOLFIELD apud KNIGHT, 2014, não paginado, tradução minha).
} 
Imagem 2 - Frame do videoclipe Ave Cesaria

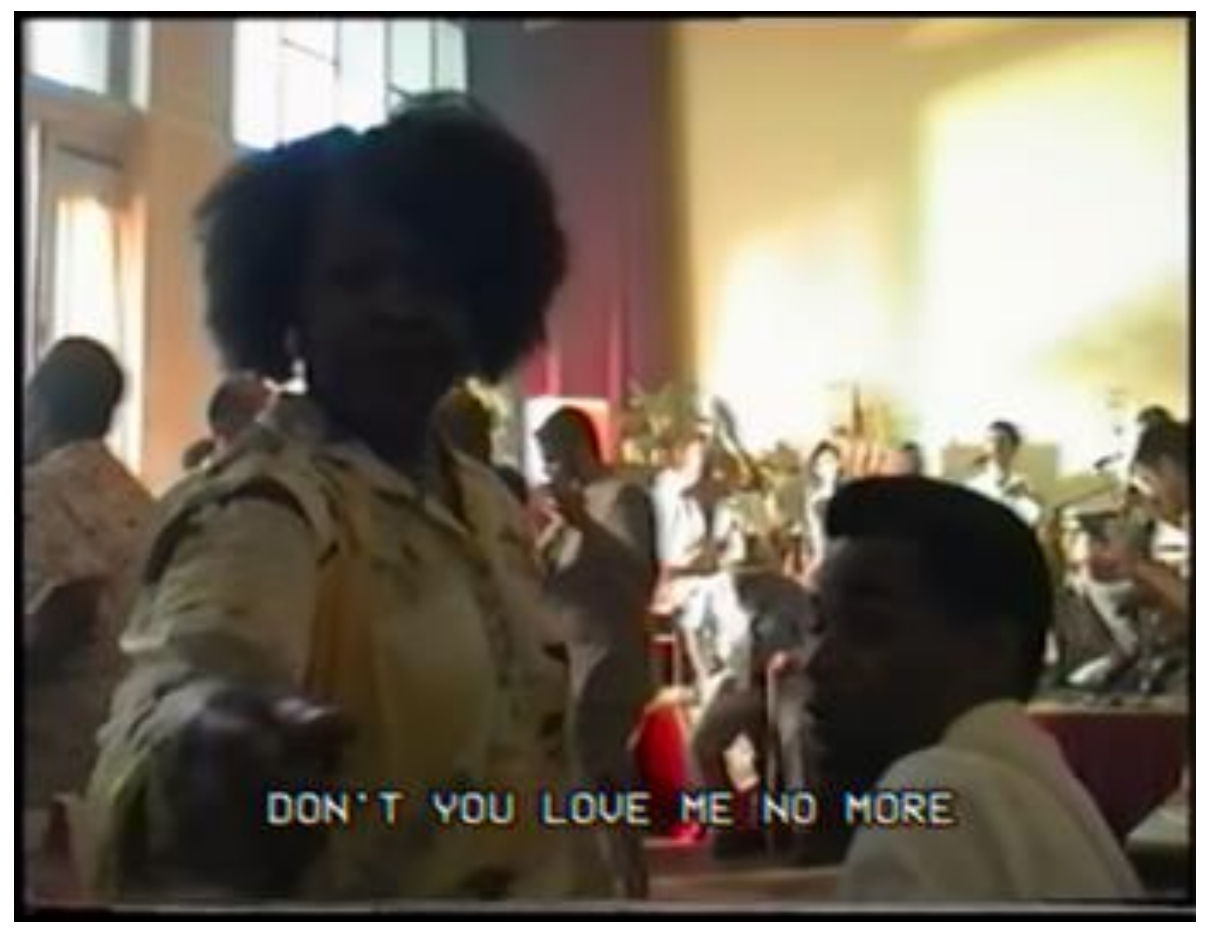

Como um coadjuvante na cena festiva, Stromae bate palmas no palco. A baixa qualidade proposital da imagem hibridiza técnica e sentido. Fonte: Stromae/Reprodução Youtube.

\section{A nostalgia nas interações: as memórias que o videoclipe constrói}

Dos quase quatro mil comentários registrados pelo Youtube (até julho de 2019) ${ }^{4}$, a ideia de nostalgia aparece como destaque sem que o elemento artístico personificado por Stromae e Cesaria Evora sejam deixados de lado. É a partir deles que a fronteira entre a arte e a nostalgia se aproximam no produto audiovisual.

A título de recorte analítico, foram selecionados 20 comentários do videoclipe com maior relevância, segundo o ranqueamento posicional do Youtube, que leva em conta curtidas e respostas atribuídas ao comentário. Dentro desse selecionado, a palavra "video" é a que mais aparece, com sete ocorrências, mas destaca-se a palavra "nostalgia", com quatro ocorrências (escrita de três formas: nostalgia, nostalgic e nostalgique).

Outras expressões também aparecem em destaque, como "like" (seis ocorrências), relacionadas ao gosto pelo produto; "reason" (quatro ocorrências), relacionando-se com uma

\footnotetext{
${ }^{4}$ Todos os números relativos ao videoclipe que seguem são relativos a essa data.
} 
razão de aprender outro idioma, especialmente o francês; e substantivos próprios, como "Stromae", "Cesaria" (Evora), "Cabo" (Verde), ocorrências que demonstram a aproximação do público com os artistas. Outro destaque é a junção das palavras "saudade" e "sodadi" que, juntas, aparecem em cinco ocorrências.

Embora as ocorrências verbais contribuam na análise de conteúdo, crê-se que ela se torne incompleta na tentativa de explicar um sentimento ligado à memória que não pode ser compreendido apenas pela ocorrência do termo nas interações dos usuários. Comentários que, por exemplo, afirmam "can't find the reason why every time $i$ watch this music video, ifeel like $i$ need to cry like a baby" referem-se explicitamente àquilo que move um sentimento nostálgico, mesmo que ele ainda não esteja organizado no indivíduo e não possa ser traduzido na própria palavra. Por isso, a análise de conteúdo escolhida se baseia na intensidade como regra de enumeração, "referente à quantidade de associações e classificações manifestadas sobre um símbolo, ideia ou tema" (FONSECA JÚNIOR, 2010, p. 295), no caso, a nostalgia.

É possível reconhecer por uma análise interpretativa que a "necessidade de chorar" manifestada pelo comentário anterior esteja ligada a esse sentimento que é difícil de explicar, mas que foi "compreendido" com as mais de 1.200 curtidas e 28 respostas que percorrem diferentes interações: pelo discurso da valorização familiar, pelo incentivo a apenas chorar sem buscar entender o sentido, pela explicação da canção e as imagens produzidas e pelo compartilhamento do sentimento pelos pares, que reforça a dimensão coletiva da memória, construída permanentemente por interações atuantes no acionamento de lembranças individuais.

A análise indica que a ideia de nostalgia se localiza na fronteira híbrida entre o triste e o feliz. Ao mesmo tempo em que toda a narrativa deste artigo buscou localizar a produção de Ave Cesaria pelo lado feliz da nostalgia, parte dos comentários selecionados partilha outro sentimento: "Why do I feel so sad by watching such a happy video?". ${ }^{6}$ As duas primeiras respostas ao comentário trazem duas importantes palavras para entender o sintoma: “It's nostalgic" e uma resposta que apenas diz: "saudade". Outro comentário, no entanto, lembra a

\footnotetext{
5 "Não consigo encontrar a razão pela qual toda vez que assisto a esse videoclipe, tenho vontade de chorar como um bebê" (tradução minha).

6 "Por que me sinto tão triste por assistir a um vídeo tão feliz?" (tradução minha).

7 "Nostalgia" (tradução minha).
} 
faceta plural da nostalgia que explica Ribeiro (2018): "There are so much powerful, melancholic, in love, and beautiful". 8

$\mathrm{Na}$ relação entre o triste e o feliz, alguns dos comentários reconhecem a felicidade explicitada no vídeo e, embora não recorram a uma tristeza nostálgica ao assisti-lo, parecem reconhecer o distanciamento de sua vida atual daquele estado de espírito reconhecido no vídeo: "If Heaven exists it must be a place like this"9 $\mathrm{e}$ "after my death $i$ hope this place will be my paradise". 10

Mas é o comentário com mais de 500 curtidas e 20 respostas que melhor explora a ideia de nostalgia, no qual o usuário busca explorar sobre si o sentimento da nostalgia: "This song makes me nostalgic for some reason, remembering my childhood, birthday parties in Haiti where I grew up with my little cousins and friends. Now we're split apart, dealing with adulthood by ourselves, and having no idea how to manage" ${ }^{11}$ Mesmo que ele indique uma nacionalidade diferente daquela aparentemente cantada por Stromae, é o tempo da infância em seu país e sua relação familiar que indica sua nostalgia. Não podemos saber onde ele reside, mas é possível que seja um haitiano que seguiu o destino de "ser diáspora", como indica Handerson (2015, p. 340). A indicação de que o Haiti ficou resguardado ao passado é clara, assim como aqueles que faziam parte de sua vida, especialmente seus primos. O breve testemunho na rede de interações sugere a proeminência desses espaços como divãs digitais, onde aspectos mais íntimos da subjetividade são expostos, como o caso da solidão e da incapacidade de gerir sua vida no presente, confissão final do usuário.

A ancoragem aplicada pelos produtos do chamado "mercado da nostalgia" pode atuar na recuperação de lembranças de um haitiano, mas também de indivíduos que, assim como Stromae, buscam referências em diversas culturas para se construir. Um dos comentários em destaque com 866 curtidas e 16 respostas diz o seguinte: "Cesaria Evora was an absolute legend!!Is this Evora's real family? If not Stromae did an excellent job in capturing Capo Verde culture. He made this video look authentically Cabo Verdean, the multiracial families, the

\footnotetext{
8 "Há tantas coisas poderosas, melancólicas, apaixonantes e lindas" (tradução minha).

9 "Se o céu existe deve se parecer com este lugar" (tradução minha).

10 "Depois que morrer espero que meu paraíso seja este lugar" (tradução minha).

11 "Essa música me deixa nostálgico por algum motivo, relembra minha infância, festas de aniversário no Haiti onde cresci com meus primos e amigos. Agora estamos separados, lidando cada um com nossas vidas adultas, e não tendo nenhuma ideia de como tocá-la" (tradução minha).
} 
Portuguese interior architecture, the West African flavour. It's so nostalgic!!!!". ${ }^{12}$ A fã entende a referência a Cabo Verde, não só pela referência a Cesaria Evora, mas pela multiculturalidade que constrói o país. E a pergunta, claro, diversas vezes realizada: "Esta família é real?". Realidade e ficção, saudade e alegria juntas, cultuadas na produção do cantor.

Os comentários flutuam entre a tristeza e a alegria e demonstram que tempo e migração estão relacionados pela característica mobilidade. Se, a priori, a migração é o deslocamento do homem no espaço, o tempo se desloca continuamente como uma unidade geral das sociedades humanas, mas também como unidade mental do indivíduo. Um homem que migra para outro lugar rompe com a temporalidade do seu espaço físico, que continua a ocorrer sem ele. Quando volta, o mesmo lugar deixado não será mais o mesmo para ele, ainda que continue idêntico a quando se deslocou. Ambos passam a seguir linhas temporais diferentes e, quando se encontrarem, tanto um quanto o outro não serão plenamente reconhecíveis.

Esta reflexão, baseada na "dupla ausência" de Sayad (1998), provavelmente atuou sobre o migrante haitiano que se sentiu nostálgico ao assistir ao videoclipe. E não é só com o migrante que a nostalgia se efetiva. Pela mobilidade do tempo, mesmo que os indivíduos se encontrem no mesmo lugar físico, estes se integram à dinâmica do deslocamento, como condição de sua própria existência. Assim, o passado, que não existe mais, só garante aos indivíduos que viveram nele a lembrança, que é criada pelo presente. E só pela condição de esquecer que a memória existe e, consigo, a nostalgia pode se efetivar.

Hartog (2013, p. 39) explora a definição de que "o tempo histórico é produzido pela distância criada entre o campo da experiência, de um lado, e o campo da expectativa, de outro" e revela nas últimas linhas do referido livro a proeminência do futuro, portador da expectativa: “O presente é, então, percebido como inferior ao futuro, o tempo torna-se um ator: se é levado por sua aceleração" (HARTOG, 2013, p. 260). Experiência e expectativa são dois lados complementares do tempo histórico, mas modificados em um regime de aceleração.

Tal como Latour, Hartog também crê no não-humano como ator. O tempo como "actante" modifica a realidade a partir de sua própria transformação. É, no meu entender, a

12 “Cesaria Évora era uma lenda absoluta!! Esta é a verdadeira família de Évora? Se não, Stromae fez um excelente trabalho na captura da cultura de Cabo Verde. Ele fez este vídeo parecer realmente cabo-verdiano, as famílias multirraciais, a arquitetura de interiores portuguesa, o sabor da África Ocidental. É tão nostálgico !!!!"” (tradução minha). 
particularidade que integra a midiatização da sociedade em sua faceta ecossistêmica, na qual as mídias sociais não se situam como meros instrumentos, mas negociam sentidos junto às práticas sociais no que tange a suas interações, discursos e contextos, tal como afirma Martino (2019). Para além da digitalização do ecossistema midiático, Couldry e Hepp (2017) exploram outro passo (o qual chamam de midiatização profunda) que intensifica esse regime de aceleração do tempo: a datificação, que passa a organizar as relações sociais pelo controle de dados, alterando a velocidade de acesso a determinados conteúdos pelo usuário, ao mesmo tempo em que a liberdade de escolha passará por um novo dilema que advogará entre o específico e o diverso.

Por fim, cabe ressaltar o desafio de analisar o fenômeno da nostalgia neste novo regime de temporalidade, no qual a mobilidade passa a ser uma palavra de ordem, também redimensionada pela modificação do espaço-tempo da globalização e a consequente diminuição de fronteiras entre o nativo e o estrangeiro. Foi possível perceber que a nacionalidade evocada no videoclipe não diz respeito à experiência "nacional" vivida pelo cantor - e por boa parte dos usuários que interagiram - porque essa categoria de experiência é insuficiente para responder às práticas socioculturais dos indivíduos. O que sinaliza ao "mercado da nostalgia" é a referência a um sentimento coletivo de lembranças que invade o individual, reconstruindo memórias como se a encenação sintetizasse algo vivido ou representasse o desejo de vivê-lo: “J'avais jamais vu ce clip même si j'avais déjà entendu la chanson. J'ai eu envie de pleurer, la mise en scène est tellement...pure, je pense qu'au delà de la musique elle même, voir ce clip nous rend tous nostalgique, des fêtes de familles, des fêtes d'enfance, de notre vie. Une telle transmission par l'image m'impressionne". 13

Mais importante do que o espaço nacional, é o espaço da celebração familiar e do encontro de gerações que crava o vínculo necessário entre o videoclipe e os usuários do Youtube. Isso, no entanto, não significa depreciar a importância das migrações neste artigo, pois o estatuto do fenômeno não se encontra prioritariamente num nacionalismo metodológico, mas na mobilidade que caracteriza os indivíduos que se deslocam no espaço e no tempo. Tempo este cada vez mais acelerado e, portanto, quase instintivamente arquivado e feito nostalgia nas realizações humanas.

\footnotetext{
13 "Eu nunca tinha visto esse clipe, embora já tivesse ouvido a música antes. Tive vontade de chorar, a encenação é tão ... pura, acho que além da música em si, ver esse clipe nos deixa todos nostálgicos, festas familiares, festas de infância, da nossa vida. Essas imagens transmitidas me impressionam” (tradução minha).
} 


\section{Referências}

ARAÚJO, Jorge. O regresso da velha senhora. Expresso. Atualidade/Arquivo. 23 set. 2011. Disponível em: https://expresso.pt/actualidade/o-regresso-da-velha-senhora=f675914. Acesso em: 16 jun. 2019.

BAUDRILLARD, Jean. Simulacros e simulações. Lisboa: Relógio D’água, 1991.

BRAGA, José Luiz. A sociedade enfrenta sua mídia: dispositivos sociais de crítica midiática. São Paulo: Paulus, 2006.

COULDRY, Nick; HEPP, Andreas. The mediated construction of reality. London: Polity, 2017.

DAWKINS, Richard. O gene egoísta. São Paulo: Companhia das Letras, 2005.

ELHAJJI, Mohammed. Mapas subjetivos de um mundo em movimento: migrações, mídia étnica e identidades transnacionais. Revista Eptic, Aracaju, v. 13, n. 2, maio/ago. 2011. Disponível em: https://seer.ufs.br/index.php/eptic/article/view/109. Acesso em: 16 jun. 2019.

ELHAJJI, Mohammed. El ghorba: entre a terra de exílio e a terra natal. Mesa de abertura. In: 20 ANOS DEPOIS: A CONTEMPORANEIDADE DO PENSAMENTO DE ABDELMALEK SAYAD. 2 fev. 2018, São Paulo. Gravação da TVPUC. Disponível em: https://www.youtube.com/watch?v=ex13PE9nBIY\&t=3431s. Acesso em: 13 maio 2019.

FONSECA JÚNIOR, Wilson. Análise de conteúdo. In: DUARTE, Jorge; BARROS, Antonio. Métodos e técnicas de pesquisa em comunicação. 2. ed. São Paulo: Atlas, 2010. p. 280-304.

GRASSI, Marzia. Identidades plurais na Europa Contemporânea: auto-percepções e representações nos jovens de origem africana em Portugal. In: GÓIS, Pedro (org.). Comunidade(s) cabo-verdiana(s): as múltiplas faces da imigração cabo-verdiana. Editorial do Ministério da Educação: Lisboa, 2008. p. 155-172.

HALBWACHS, Maurice. A memória coletiva. São Paulo: Vértice, 1990.

HANDERSON, Joseph. Diáspora: as dinâmicas da mobilidade haitiana no Brasil, Suriname e na Guiana Francesa. 2015. Tese de Doutorado (Programa de Pós-graduação em Antropologia Social, Museu Nacional) - Universidade Federal do Rio de Janeiro, Rio de Janeiro, 2015.

HARTOG, François. Regimes de historicidade: presentismo e experiências do tempo. Belo Horizonte: Editora Autêntica, 2013. 
HENRIQUES, Joana. O país que tem mais gente fora do que dentro. Público, 5 jul 2015. Disponível em: https://www.publico.pt/2015/07/05/mundo/noticia/o-pais-que-tem-mais-gentefora-do-que-dentro-1700904. Acesso em: 12 jul. 2021.

HIRSCH, Olivia. De imigrantes a estudantes: a formação no exterior como alternativa de mobilidade social em Cabo Verde? In: ENCONTRO ANUAL DA ANPOCS, 32., 2008, Caxambu. Anais [...] Associação Nacional de Pós-Graduação e Pesquisa em Ciências Sociais, 2008. Disponível em: https:/www.anpocs.com/index.php/papers-32-encontro/gt-27/gt2515/2540-oliviahirsch-de-imigrantes/file. Acesso em: 12 jul. 2021.

HUYSSEN, Andreas. Seduzidos pela memória: arquiteturas, monumentos, mídia. Rio de Janeiro: Aeroplano, 2000.

JANOTTI JR., Jeder. Gêneros musicais, performance, afeto e ritmo: uma proposta de análise midiática da música popular massiva. Revista Contemporânea, Salvador, v. 2, n. 2, p. 189204, 2004. Disponível em: https://repositorio.ufba.br/ri/bitstream/ri/4741/3/3418-8153-1PB.pdf. Acesso em: 24 jun. 2019.

KNIGHT, David. Stromae 'Ave Cesaria' by Henry Scholfield. Promonews. 16 out 2014. Disponível em: https://www.promonews.tv/videos/2014/10/16/stromae-ave-cesaria-henryscholfield/29583. Acesso em: 24 jun. 2019.

LATOUR, Bruno. Reassembling the social: an introduction to Actor-Network-Theory. Nova York: Oxford University Press, 2005.

MARTINO, Luís Mauro Sá. Rumo a uma teoria da midiatização: exercício conceitual e metodológico de sistematização. Intexto, Porto Alegre, n. 45, p. 16-34, maio/ago. 2019. Disponível em: https://seer.ufrgs.br/intexto/article/view/77889/50501. Acesso em: 24 jun. 2019.

PASSOS, Úrsula. Com hip-hop melancólico, belga Stromae é comparado a Jacques Brel. Folha de S. Paulo, São Paulo, 07 fev. 2014. Ilustrada. Disponível em: https://www1.folha.uol.com.br/ilustrada/2014/02/1408930-com-hip-hop-melancolico-belgastromae-e-comparado-a-jacques-brel.shtml. Acesso em: 16 jun. 2019.

PRIMO, Alex. O que há de social nas mídias sociais? Reflexões a partir da Teoria Ator-Rede. Contemporânea, Salvador, v. 10, n. 3, p. 618-641, set./dez. 2012. Disponível em: https://www.lume.ufrgs.br/bitstream/handle/10183/166331/001047723.pdf?sequence=1\&isAll owed=y. Acesso em: 24 jul. 2019.

PUHL, Paula Regina; ARAÚJO, Willian. YouTube como espaço de construção da memória em rede: possibilidades e desafios. Famecos, Porto Alegre, v. 19, n. 3, p. 705-722, set-dez 2012. Disponível em: https://revistaseletronicas.pucrs.br/ojs/index.php/revistafamecos/article/view/12895/8602. Acessao em: 24 jun. 2019. 
RIBEIRO, Ana Paula G. Mercado da nostalgia e narrativas audiovisuais. Revista E-Compós, Brasília, v. 21, n. 3, set./dez. 2018. Disponível em: https://www.e-compos.org.br/ecompos/article/view/1491/1861. Acesso em: 24 jun. 2019.

ROSNAY, Joël de. Memória em rede e intercriatividade. In: CASALEGNO, Federico. Memória cotidiana: comunidades e comunicação da era das redes. Porto Alegre: Sulina, 2006.

SAYAD, ABDELMALEK. A imigração ou os paradoxos da alteridade. São Paulo: Edusp, 1998.

SOARES, Thiago. O videoclipe como articulador dos gêneros televisivo e musical. In: CONGRESSO BRASILEIRO DE CIÊNCIAS DA COMUNICAÇÃO DA REGIÃO NORDESTE, 9, 2007, Salvador. Anais [...]. São Paulo: Intercom, 2007a. Disponível em: http://www.intercom.org.br/papers/regionais/nordeste2007/resumos/r0264-1.pdf. Acesso em: 24 de jul. 2019.

SOARES, Thiago. O videoclipe como semblante midiático: estratégias discursivas na construção da imagem da cantora Björk. In: CONGRESSO BRASILEIRO DE CIÊNCIAS DA COMUNICAÇÃO, 30., 2007, Santos. Anais [...]. São Paulo: Intercom, 2007b. Disponível em: http://www.intercom.org.br/papers/nacionais/2007/resumos/R0204-1.pdf. Acesso em: 24 de jul. 2019.

SODRÉ, Muniz. A ciência do comum: notas para o método comunicacional. Petrópolis: Vozes, 2014.

TURNER, Joe. (En)gendering the political: citizenship from marginal spaces. Citizenship Studies, n. 20, v. 2, p. 141-155, 2016. Disponível em: https://www.tandfonline.com/doi/full/10.1080/13621025.2015.1132569. Acesso em: 19 jul. 2019.

Submetido em: 16.08.2019.

Aprovado em: 31.12.2020. 